\title{
Faculty Perceptions toward Critical Thinking among Kasetsart University Students
}

\author{
Chakree Kerdsomboon $^{1}$ \& Jittinun Boonsathirakul ${ }^{2}$ \\ ${ }^{1}$ Doctoral Student in the Department of Education and Human Potentials Development, Hua-Shih College of \\ Education, National Dong Hwa University, Taiwan, and Lecturer in the Department of Educational Psychology \\ and Guidance, Faculty of Education, Kasetsart University, Bangkok, Thailand \\ ${ }^{2}$ Associate Professor in the Department of Educational Psychology and Guidance, Faculty of Education, \\ Kasetsart University, Bangkok, Thailand \\ Correspondence: Chakree Kerdsomboon, Department of Educational Psychology and Guidance, Faculty of \\ Education, Kasetsart University, Bangkok, Thailand. Tel: 66-929-789-893. E-mail: chakree.ker@ku.ac.th
}

Received: July 8, $2021 \quad$ Accepted: August 4, $2021 \quad$ Online Published: August 10, 2021

doi:10.5539/hes.v11n3p108 URL: https://doi.org/10.5539/hes.v11n3p108

\begin{abstract}
This study investigated faculty perceptions toward critical thinking among students in Thai universities and how this might influence how they teach, and they might instill this form of thinking in their students. The data source was semi-structured interviews with six faculty from the Educational Psychology and Guidance fields in Thai universities via Line and Facebook application. It has been found that faculty perceived that critical thinking helps students in their decision in daily life problem appropriately. Even though teachers perceived that they are encouraging their students to think critically in the classrooms, they are only concerned with comprehending the subject matters. Detailed discussions regarding the perceptions of faculty on students' critical thinking are provided.
\end{abstract}

Keywords: critical thinking, faculty perceptions, college students

\section{Introduction}

The development of critical thinking is normally acquiescent as a key aim of higher education (Moore, 2013). Students ought to make decisions based on a good idea of obtaining information. Studies show that students' critical thinking abilities improve during their college years (Gelling, 20003; Giancarlo, 2001). In Thailand, there are many research on critical thinking. There is, however, a lack of research on the perception of the teacher towards critical thinking.

Despite the fact that critical thinking is seen as a crucial aim of education. There are indications that many college teachers do not fully comprehend how to properly teach critical thinking or improve higher-order cognitive skills (Ahuna et al., 2014) and they are unable to include critical thinking activities in their course curricula (Shim \& Waclczak, 2012). Many college faculties proclaim to promote students to explicate critical thinking but using a narrative teaching and focusing on students' assignments and memorization attempts (Ahuna et al., 2014) and lower-level thinking tasks which are not motivated critical thinking (Duron et al., 2006). In higher education, a narrative teaching is a popular strategy. Students may not be motivated to engage in active learning of critical thinking (Duron et al., 2006). To encourage pupils to think critically and actively learn, teacher must dispel the myth that learners cannot learn unless they are accompanied by a teacher. According to choy (2003), pointed, many teachers still believe that students must be taught before they can learn. Teachers should also be adaptable and Black (2005) explain to students that there are frequently multiple solutions to a problem. As a result, teachers' impressions of how they learn must be taken into consideration.

Sharing and communicating with others are essential for critical thinking to occur. Hence, critical thinking necessitates introspection, followed by interaction with others (Vaske, 2001). This research investigates teachers' attitudes regarding critical thinking among Thai University students. And this might affect the way they teach, as well as whether they might inspire their students to think in this way.

The objective of this study aims to explore faculty perceptions toward Thai university students as follows: 
1. What are the perceptions of faculty on critical thinking?

2. What are the perceptions of faculty of students' critical thinking abilities?

\section{Literature Review}

\subsection{Critical Thinking}

There are many definitions of critical thinking which have been identified. Benjamin Bloom was the first educational psychologist who highlighted Bloom's taxonomy a few decades ago (Laurer, 2005). It was apprehended that a higher level of cognitive ability involving critical thinking was associated with levels of analysis, synthesis, and evaluation, whereas lower levels of cognitive ability, namely knowledge, comprehension, and application were only concerned with remembering, relating and applying information respectively (Duron et al., 2006; Islamiyah \& Sholakhuddin, 2020; Saulius et al., 2021).

Liu et al. (2014) appraised seven critical thinking frameworks to determine common components. Critical thinking entails identifying, analyzing, synthesizing, and evaluating information in order to provide actionable knowledge to make effective decisions (Giancarlo \& Facione, 2001; Liu et al., 2011). Alwehaibi (2012) summarize critical thinking as the ability to make sense of new information.

Critical thinking, according to Riddell (2007), should not be defined but rather described through its elements and features, stages, and characteristics as how critical thinking specialists have done. Previous research has also summarized critical thinking as a reflection; identification and appraisal of assumptions; inquiry, interpretation and analysis; and reasoning and judgment; with the consideration of context. As a result, critical thinking is a sophisticated process that necessitates higher levels of cognitive skills in information processing.

\subsection{Faculty Perceptions of Learning}

Sainn and Ugwuegbu (1980) determined that perception can define as "the process by which we extract meaningful information from physical stimulation. It is the way we interpret our sensations." There are three main points of perception as follows;

Firstly, perception is influenced not only by the stimulus but also iillustrated by an individual's experience, intention, and social needs. Secondly, when perceiving something, the perceiver is not passive and indifferent, but is actively selecting information and generating hypotheses in order to determine what is actually happening. Finally, perception is a higher mental process that allows an individual to construct a model of his or her world in order to forecast future events and deal with them properly. Hence, physical stimulation from an individual's sensory receptors provides relatively limited information and cannot be interpreted unless there is additional information derived from past experiences and memory. When physical stimuli are properly interpreted, they will become an individual's perceptions.

There has been much controversy about how teachers' perceptions affect their students (Chee \& Phaik, 2009). Teachers should consider how their pupils perceive them in the classrooms because this can intertwine with personal philosophies and attitudes toward teaching (Horwitz, 1989). Therefore, asking questions to teachers about their perceptions of the critical thinking is very important.

\section{Method}

The interpretive approach was used in this study. In this approach, the individual constructs personal meaning when dealing with the environment around them in order to make it meaningful (Radnor, 2002), implying the need for an in-depth and profound analysis of the data obtained. The goal is to perceive reality as socially constructed, with individuals' behaviors constantly interpreted and reinterpreted to provide meaningful information about behavior, generally within a specific context (Holliday, 2002; Radnor, 2002). The meanings gathered in this way are actually conceptualized and temporary knowledge (Greene, 2000). The responses were categorized based on themes derived from the data.

\subsection{Participants}

Six faculties, who were currently teaching educational psychology and guidance, were interviewed via Line and Facebook application (two of male and four of female). The average teaching experience was 13.3 years. The least teaching experience was five years; the longest was thirty years. Table 1 shows the background of participants. 
Table 1. Participant interviewee profile

\begin{tabular}{|c|c|c|c|}
\hline Participant & Year teaching & Subject Taught & Educational background \\
\hline \multirow[t]{3}{*}{ A } & 11 & - Principles of guidance & Ph.D. in Counseling \\
\hline & & - Child psychology & M.A in Educational psychology and guidance \\
\hline & & - Individual difference & B.A. in Mass communication \\
\hline \multirow[t]{4}{*}{ B } & 10 & - Educational psychology & Ph.D. in Psychology of Human \\
\hline & & - Principles of guidance & Potentials Development \\
\hline & & - Classroom motivation & M.A in Educational psychology and guidance \\
\hline & & $\begin{array}{l}\text { - Behavioral Modification } \\
\text { in classroom }\end{array}$ & B.E. in Social studies \\
\hline \multirow[t]{2}{*}{$\mathrm{C}$} & 5 & - Psychology for teacher & M.A. in Educational psychology \\
\hline & & $\begin{array}{l}\text { - Educational psychology } \\
\text { and counseling } \\
\text { - Inclusive education }\end{array}$ & B.E. in Educational psychology and guidance \\
\hline \multirow[t]{2}{*}{$\mathrm{D}$} & 19 & $\begin{array}{l}\text { - Educational psychology } \\
\text { - Creativity } \\
\text { - Rehavioral Modification }\end{array}$ & $\begin{array}{l}\text { Ph.D. in Educational administration } \\
\text { and leadership }\end{array}$ \\
\hline & & $\begin{array}{l}\text { - Behavioral Modification } \\
\text { in classroom }\end{array}$ & $\begin{array}{l}\text { M.A. in Population development } \\
\text { M.A. in Educational psychology and guidance } \\
\text { B.E. in Guidance }\end{array}$ \\
\hline \multirow[t]{2}{*}{$\mathrm{E}$} & 5 & - Psychology for teacher & M.A. in Educational psychology and guidance \\
\hline & & $\begin{array}{l}\text { - Personality and adjustment } \\
\text { - Teacher professional } \\
\text { development }\end{array}$ & B.A. in History \\
\hline \multirow[t]{4}{*}{$\mathrm{F}$} & 30 & - Educational psychology & Ph.D. in Curriculum and instruction: \\
\hline & & - Principle of guidance & Students with learning disabilities \\
\hline & & - Buddhist psychology & M.A. Counseling and student services \\
\hline & & & B.E. Counseling psychology and guidance \\
\hline
\end{tabular}

\subsection{Instrument}

The interview questions were employed to evoke data for this exploration. The six respondents were asked to complete a questionnaire with six questions. The questions were designed to elicit their perceptions on critical thinking. The interview questions were semi-structured to allow respondents to answer in the best way possible. A review of relevant literatures was used to develop the topics for the interview questions. An initial list of ten questions was reduced to a final list of six questions. Table 2 displays the list of questions. The authors interview six faculties from the department of Education Psychology and Guidance, Thai universities via Line and Facebook application during $23^{\text {rd }}$ October 2020 to $27^{\text {th }}$ October 2020.

Table 2. List of questions on the questionnaire on faculty's perceptions of critical thinking

\begin{tabular}{ll}
\hline \multicolumn{1}{c}{ Questions } \\
\hline 1 & From your perspective, what is critical thinking? \\
2 & Do you as a teacher encourage critical thinking in your classroom? If so, how do you know? \\
& And how do you encourage or not encourage it? \\
3 & Do you think critical thinking should play an important role in the curriculum? \\
4 & What challenges do students face when you try to teach them critical thinking? If so, please identify them. \\
5 & Do you think that your students in general are good critical thinkers? \\
6 & Do exams include critical thinking questions? \\
\hline
\end{tabular}

\subsection{Analytic Strategy}

Inductive analysis was used to examine the transcripts. The main categories were allowed to emerge from the data after several readings. The transcripts were read several times to identify key points that could be classified. Another researcher checked for consistency in the categorization of the data after the last categorization.

\section{Results and Discussion}

From figure 1, the analysis of the data's salient points yielded four categories of faculty perceptions of critical thinking. These classifications will be used to deliver answers to research questions. 


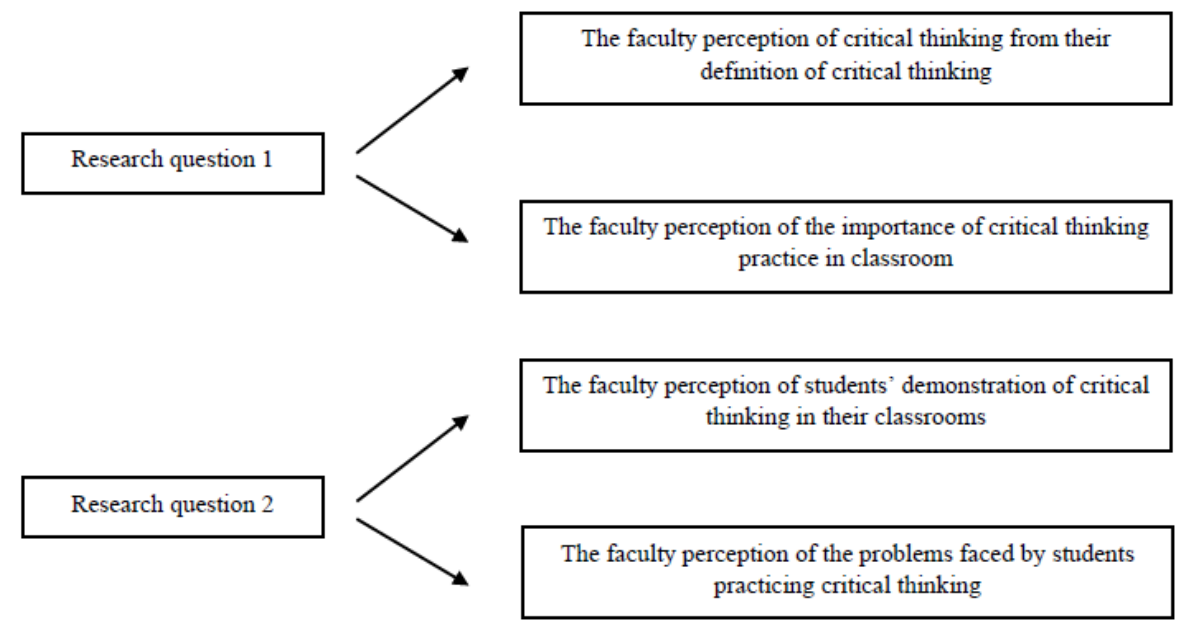

Figure 1. Categories of faculty perceptions of critical thinking

\subsection{What are the Perceptions of Faculty on Critical Thinking?}

The results earned from the interpretation of two of the categories were used to answer research question 1. There were the faculties' perception of critical thinking from their definitions of critical thinking and faculty perception of the importance of critical thinking practice in the classrooms.

\subsubsection{The Faculty Perception of Critical Thinking from their Definition of Critical Thinking}

All of the respondents stated the meaning of critical thinking as a thinking process that helps students in the decision making in various problems appropriately. For example, one of the interviewees said

"Critical thinking requires a process of thinking by perceiving information and then processing it into a response by exploring and thinking in many aspects before making a decision."

On a similar of another respondent said,

"I think critical thinking is a systematic thinking process and may involve the other credibility sources include decision making."

Critical thinking relates to logical reasoning, and it plays a part in helping students analyze, synthesize, and evaluate. For instance, one of them explained,

"Critical thinking is a matter of reasoning. For example, if you ask the student why he or she decided to study at Kasetsart University, then the student replies that because the university is close to his or her house or because Kasetsart University has a lot of green trees. This is not the way to think critically. Critical thinking requires logical reasoning."

Four of the respondents also expressed that critical thinking consists of thinking in six levels of Bloom's taxonomy. One respondent commented,

"I think knowledge and memory are very important. In addition, it (knowledge) must be analyzed, classified, must have synthesis. Finally, it must be judged and evaluated."

The faculty perception of the importance of critical thinking practice in the classroom. All of the interviewees were claimed that practicing critical thinking in their classrooms brought good results. Four respondents said that critical thinking is essential for students today develop critical thinking skills for future success. For example, one of the respondents commented,

"I mainly teach students from the faculty of education. They will work with students in the future. Critical thinking is one of the skills that will support them to teach their students effectively."

One of the respondents added that critical thinking benefits students to live deliberately and prevent conflicts with others:

"One thing that society must accelerate to cultivate for the youth is to make them be aware of how to live, which is critical thinking. Since the information is produced and spread very fast, it may lead to conflict, disharmony, or social unrest if the youth could not synthesize or evaluating information gathered from." 
One of respondents added about how critical thinking is importance with comment:

"Critical thinking is the skill to connect a lot of varieties view of seeing the problems without using our own opinions to judge the problems. As the result, the student is to confront the reality and face the obstacles and problems efficiency."

\subsubsection{Discussion}

The answers revealed that the respondents had the same perceiving about critical thinking. They perceived that critical thinking was a procedure of thinking that would assist pupils in dealing with everyday situations or problems. They also thought that critical thinking logical reasoning which helped students analyze, synthesis and evaluation their daily lives situations.

\subsection{What are the Faculty Perception of Students'Abilities to think Critically?}

The findings from the analysis of two of the categories were used to answer research question 2. There are faculty perceptions of students' critical thinking demonstrations in their classrooms as well as faculty perceptions of the problem faced by students practicing critical thinking.

\subsubsection{The Faculty Perception of Students' Demonstration of Critical Thinking in their Classrooms}

All of the faculties perceive that their students can think critically, but do not like to express students' opinion. The faculties perceive that their students do practice critical thinking in their classrooms. One interviewee said,

"I don't know whether the students think critically or not because he or she has no response. Some students do not response because of their shy personality."

Another respondent expressed a similar viewpoint with the following comment:

"I will be able to recognize that the students have critical thinking when interacting or communicating with logical answers with adequate evidence from basic knowledge or experiences."

\subsubsection{The Faculty Perception of the Problems Faced by Students by Students Practicing Critical Thinking}

All of the respondents perceived that the characteristics of students in each department are different. As a whole, most students are characterized by being passive learners, as one respondent noted:

"The nature of students in each department is different. Some departments like to criticize, but some departments are passive learners."

On a similar note another respondent commented,

"Sixty to seventy percent of Thai students are lazy to think. When teachers assign tasks, they will perform work perfunctorily and do not like the challenge. So, the important thing is to divide the work into several (small) pieces. Gradually instill the thinking process, then students will be more active learners."

Another respondent commented:

"We cannot teach critical thinking directly. The teachers should prepare students to have characteristic of critical thinking persons. For example, the students should have self-awareness, open mind to listen to others and open mind set. The teachers can use contemplative education to foster critical thinking in the students.

All of respondents perceived that they taught students to think critically, but they agreed that the subjects they taught focus on theories, which required the contents of basic knowledge. Therefore, it was sometimes difficult to incorporate viewpoints of critical thinking into the lessons. For instance, one faculty explained,

"I have to admit that sometimes I cannot include critical thinking throughout. For example, some courses have a lot of theoretical content. I always concern about how I could finish all of this before the end of the semester or not."

One respondent expressed his concern about the cultural context, which is a barrier to thinking critically. He commented,

"It is not easy to change the cognitive. For example, in a local culture (northern Thailand), if you help someone who is in trouble, you cannot receive the reward. I used to ask my students that can they give another reason that does not relate with religious belief? The impact is not so significant, but I have to prepare well."

\subsubsection{Discussion}

It would seem that students have a different critical thinking ability regarding of department. The respondent perceived that each department requires a dissimilar proportion of critical thinking. This finding is supported by 
Bakir (2014) who noted that the critical thinking different regarding the pre-service teacher's department. Eigenberger et al. (2001) also found that students of a different department in education field was difference between critical thinking scores.

The finding revealed that the respondents found their students passive and inhibited during the discussion to improve critical thinking could imply that students' and faculty perceptions of the classroom learning are very different. This supports Horwitz's (1989) findings that the way teachers perceive their students would influence the learning that takes place in the classroom.

For concerning about the cultural contexts were as a barrier to think critically, Jones (2006) who investigated the effects of culture and context on critical thinking and students. The study found that even though even though cultural differences are important, the manner in which a subject and assessment task is presented to students has a significant impact on learning.

\section{Conclusion}

The findings stated that respondents perceive the critical thinking is important for students. They believe that critical thinking helps students in the decision in daily life problems properly. They believe that students' ability to communicate concepts are important in their own words, they indicate that they were critical thinkers. According to Black (2005) pointed that critical thinking requires students to dissect their own ideas: investigate their reasoning using criteria such as clarity, accuracy, relevancy, logic, and justice. This appears to indicate that the abilities have a great grasp of critical thinking. and how to improve students to think critically. Their concept of critical thinking reflects their lack of knowledge of the topic. This indicates that critical thinking could only be taught by teachers who have a clear understanding of critical thinking abilities and how to include them into their courses so that students can transition to this way of thinking more easily.

The findings also imply that teachers are skeptical that most of their students will be able to develop critical thinking abilities on their own. Many participants believe their students are afraid of sharing and lack the language skills to effectively express themselves. Black (2005) who studied about teaching students to think critically. recommended that in order to ensure the success of critical thinking in the classroom, an environment of high expectations and teacher warmth that encourages students to express their opinions should be present. Teachers' tendency to offer the essential materials and the fact that they needed to finish their syllabi suggested that they weren't always able to include critical thinking into their courses. Teachers appear to be conflicted between wanting to encourage critical thinking in their students and needing to finish their courses. This is a problem since the institutions' governing and licensing bodies may be unaware of the requirements and time restrictions put on teachers. Even if effective communication is essential in higher education, Duron et al. (2006) pointed out that, it frequently does not encourage students to engage in active learning of critical thinking. Teachers' tendencies to give all required learning materials, as well as the obligation to complete syllabuses, would suggest a fairly structured style to teaching. Critical thinking is a skill that must be trained on a regular basis and incorporated into classroom instruction.

\section{Suggestion}

More research is needed to determine how faculty members perceive meeting expected requirements and whether time constraints could be a barrier from effectively incorporating critical thinking into their lessons.

Since faculties in the field of educational psychology are familiar with theories of learning and teaching which related to critical thinking skills, the results of this study reveal a strong understanding of critical thinking. For this reason, future studies should study the perception of faculty from other disciplines.

Classroom observation could be conducted to support this study and check the consistency of the information provided by the respondents.

\section{References}

Ahuna, K. K., Tinnesz, C. G., \& Kiener, M. (2014). A new era of critical thinking in professional programs. Transformative Dialogues: Teaching \& Learning Journal, 7(3), 1-9. Retrieved from https://www.kpu.ca/sites/default/files/Transformative\%20Dialogues/TD.7.3.7_Ahuna_etal_New_Era_of_Cr itical_Thinking\%20.pdf

Bakir, S. (2014). Critical thinking dispositions of pre-service teachers. Educational Research and Reviews, 10(2), 255-233. https://doi.org/10.5897/ERR2014.2021

Black, S. (2005). Teaching students to think critical. The education digest, 70(6), 42-47. Retrieved from https://eric.ed.gov/?id=EJ741259 
Chee, C. S., \& Phaik, K. C. (2009). Teacher perceptions of critical thinking among students and its influence on higher education. International Journal of Teaching and Learning in Higher Education, 20(2), 198-206. Retrieved from https://files.eric.ed.gov/fulltext/EJ864337.pdf

Choy, S. C. (2006). An investigation into the changes in perceptions of and attitudes towards learning English in a Malaysian college. International Journal of Teaching and Learning in Higher Education, 18(2), 120-130. Retrieved from https://files.eric.ed.gov/fulltext/EJ1068054.pdf

Duron, R., Limback. B., \& Waugh, W. (2006). Critical thinking framework for any discipline. International Journal of Teaching and Learning in Higher Education, 17(2), 160-166. Retrieved from https://www.isetl.org/ ijtlhe/pdf/IJTLHE55.pdf

Facione, P. A., \& Facione, N. (1992). The california critical thinking disposition inventory (CCTDI), and the CCTDI test manual. Millbrae, CA: California academic press.

Gellin, A. (2003). The effect of undergraduate student involvement on critical thinking: a meta-analysis of the literature 1991-2000. Journal of College Student Development, 44, 746-762. https://doi.org/10.1353/csd.2003.0066

Giancarlo, C. A., \& Facione, P. (2001). A look across four years at the disposition towards critical thinking among undergraduate students. The Journal of General Education, 50, 29-55. https://doi.org/10.1353/jge.2001.0004

Holliday, A. R. (2002). Doing and writing qualitative research. London: Sage. Retrieved from https://www.researchgate.net/publication/277215497_Adrian_Holliday_Doing_and_Writing_qualitative_res earch_Sage_Publication2002

Horwitz, E. K. (1989). Facing the blackboard: student perceptions of language learning and the language classroom. ADFL Bulletin, 20(3), 61-64. Retrieved from https://eric.ed.gov/?id=EJ390710

Islamiyah, M., \& Sholakhuddin, M. A. F. (2020). Investigating Indonesian master's students' perception of critical thinking in academic writing in a British university. The Qualitative Report, 25(12), 4402-4422. Retrieved from https://nsuworks.nova.edu/tqr/vol25/iss12/12/

Jones, A. (2006). Culture and context: critical thinking and student learning in introductory macroeconomic. Studies in Higher Education, 30(3), 339-354. https://doi.org/10.1080.03075070500095788

Laure, T. (2005). Teaching critical-thinking skills using course content material. Journal of college science teaching, 34(6), 34-44. Retrieved from https://eric.ed.gov/?id=EJ752557

Liu, O. L., Frankel, L., \& Roohr, K. C. (2014). Assessing critical thinking in higher education: current state and directions for next-generation assessment. ETS Research reports series, 2014(1), 1-23. https://doi.org/10.1002/est2.12009

Morre, T. (2013). Critical thinking: Seven definitions in search of a concept. Studies in Higher Education, 38, 506-522. https://doi.org/10.1080/03075079.2011.586995

Radnor, H. A. (2002). Researching your professional practice: Doing interpretive research. London: Open University Press.

Riddell, T. (2007). Critical assumptions: Thinking critically about critical thinking. Journal of Nursing Education, 46(3), 121-126. https://doi.org/10.3928/01484834-20070301-06

Sainn, G., \& Ugwuegbu, D. C. E. (1980). Education psychology in a changing world. London" UnwinHyman.

Saulius, T., \& Malinauskas, R. K. (2021). Involvement of critical thinking education in university studies: A qualitative research. European Journal of Contemporary Education, 10(1), 113-126. https://doi.org/10.13187/ejced.2021.1.113

Shim, W., \& Walczak, K. (2012). The impact of faculty teaching practices on the development of students' critical thinking skills. International Journal of Teaching and Learning in Higher Education, 24(1), 16-30. Retrieved from https://files.eric.ed.gov/fulltext/EJ977179.pdf

Vaske, J. M. (2001). Critical thinking in adult education: An elusive quest for a definition of field (Unpublished doctoral thesis). Drake University, des Moines, Iowa. 


\section{Copyrights}

Copyright for this article is retained by the author(s), with first publication rights granted to the journal.

This is an open-access article distributed under the terms and conditions of the Creative Commons Attribution license (http://creativecommons.org/licenses/by/4.0/). 